\title{
Long Term Survivor
}

National Cancer Institute

\section{Source}

National Cancer Institute. Long Term Survivor. NCI Thesaurus. Code C17658.

Patients who have survived several years 